\title{
PENGARUH PERPUTARAN KAS, PERPUTARAN PIUTANG DAN PERPUTARAN PERSEDIAAN TERHADAP PROFITABILITAS (RETURN ON ASSET) (STUDI PADA PERUSAHAAN PROPERTY DAN REAL ESTATE YANG TERDAFTAR DI BURSA
} EFEK INDONESIA PERIODE 2012 - 2017)

\author{
${ }^{1}$ Anna Eka Gustriyana \\ ${ }^{2}$ Nunung Nurhasanah \\ Pasca Sarjana Manajemen Universitas Singaperbangsa Karawang \\ anna.gustriyana@gmail.com, \\ nnurhasanah.jihan@gmail.com
}

\begin{abstract}
This study aims to examine the factors (Cash Turnover, Account Receivable Turnover dan Inventory Turnover to profitability ROA Study In Company Property and Real Estate Listed on the Indonesia Stock Exchange) that influence profitability of property and real estate companies listed on the Indonesia Stock Exchange. The results of the study show that variable Cash Turnover has partially significant effect to profitability (Return On Asset), Variable Account Receivable Turnover has partially significant not effect to profitability ROA and variable Inventory Turnover has partially significant not effect to profitability ROA. Simultaneously variable cash turnover, accounts receivable turnover, and inventory turnover have a significant effect on profitability ROA.
\end{abstract}

Key WordS: Profitability, ROA, Cash Turnover, Accounts Receivable Turnover, Inventory Turnover

\begin{abstract}
ABSTRAK
Penelitian ini bertujuan untuk menguji faktor-faktor yang mempengaruhi profitabilitas perusahaan property dan real estate yang terdaftar di BEI. Faktor- faktor tersebut adalah perputaran kas, perputaran piutang dan perputaran persediaan terhadap profitabilitas ROA perusahaan property dan real estate yang terdaftar di BEI. Hasil penelitian menunjukan bahwa variabel Perputaran Kas berpengaruh signifikan terhadap Profitabilitas ROA, Perputaran Piutang tidak berpengaruh terhadap Profitabilitas ROA dan Perputaran Persediaan tidak berpengaruh terhadap Profitabilitas ROA Secara simultan menunjukan bahwa Perputaran Kas, Perputaran Piutang dan Perputaran
\end{abstract}

Kata Kunci: profitabilitas, ROA, Perputaran Kas, Perputaran Piutang, Perputaran Persediaan 


\section{PENDAHULUAN}

Perkembangan PDB sektor Real estate tersebut tidak terlepas dari meningkatnya kredit perbankan ke sektor Real estate dan juga Kredit Pemilikan Rumah (KPR). Gambar 1.1 menunjukkan bahwa relaksasi Loan to Value atau LTV yang dilakukan di bulan Juni 2015 dapat kembali mendorong pertumbuhan kredit perbankan ke sektor Real estate sekaligus KPR yang terus menunjukkan tren yang meningkat. PDB untuk real estate merupakan salah satu indikator untuk melihat pertumbuhan pada sektor industri property. Sehingga dapat diketahui tren perkembangan property selama ini, dimana Data Badan Pusat Statistik (BPS) terbaru menunjukkan, pertumbuhan PDB pada lapangan usaha Real estate pada triwulan III-2016 tumbuh melambat, baik triwulanan maupun tahunan, masing-masing sebesar 0,47 persen (qtq) dan 3,70 persen (yoy), dibandingkan 0,68 persen (qtq) dan 4,46 persen (yoy). Pertumbuhan indeks harga property residensial terbaru juga masih melanjutkan tren pelambanan, baik triwulanan maupun tahunan. Pada triwulan II-2016 indeks harga property residensial sebesar 0,64 persen (qtq) dan 3,39 persen (yoy) namun pada triwulan III-2016 masing-masing turun menjadi 0,36 persen (qtq) dan 2,75 persen (yoy).

Untuk menyikapi kondisi tersebut, perusahaan property dan realestat harus mampu mengungguli persaingan dan memperoleh keuntungan/laba yang optimal dan mampu menggunakan aktivanya secara produktif, oleh karena itu modal kerja sebagai salah satu komponen terpenting dari aktiva harus dikelola dan dimanfaatkan secara efektif dan produktif, sehingga mampu meningkatkan profitabilitas perusahaan.

Besar kecilnya modal kerja dapat ditambah atau dikurangi sesuai kebutuhan perusahaan. Modal kerja selalu dalam keadaan operasi atau berputar dalam perusahaan selama perusahaan yang bersangkutan dalam keadaan usaha. Periode perputaran modal kerja dimulai dari saat dimana kas diinvestasikan dalam komponen-komponen modal kerja sampai saat dimana kembali lagi menjadi kas, dimana menurut Sutrisno (2012:47) besarnya modal kerja ditentukan dengan cara menghitung perputaran elemen-elemen pembentuk modal kerja seperti perputaran kas, perputaran piutang dan perputaran persediaan.

Menurut Kasmir (2011:182), menyatakan bahwa perputaran modal kerja atau working capital turn over merupakan salah satu rasio untuk mengukur atau menilai keefektifan modal kerja perusahaan selama periode tertentu. Artinya seberapa banyak modal kerja berputar selama satu periode atau dalam satu periode.

Untuk mengukur tingkat profitabilitas suatu perusahaan dibutuhkan alat analisis untuk 
Anna Eka Gustriyana, Nunung Nurhasanah

Vol 4 No 2

ISSN : 2541-6995

E ISSN : 2580-5517

menilainya. Alat analisis yang digunakan untuk mengetahui kinerja keuangan suatu perusahaan yaitu dengan menggunakan rasio - rasio keuangan. Rasio profitabilitas sering digunakan untuk mengukur efektifitas manajemen berdasarkan hasil pengembalian yang diperoleh dari penjualan dan investasi atau dengan kata lain rasio profitabilitas adalah alat untuk mengukur efisiensi penggunaan modal dalam suatu perusahaan, yaitu dengan membandingkan antara laba dengan modal yang digunakan dalam operasi. Return on asset (ROA) atau sering disebut sebagai rentabilitas ekonomis adalah salah satu bentuk dari rasio profitabilitas yang dimaksud untuk mengukur kemampuan perusahaan dengan keseluruhan dana yang ditanamkan dalam aktiva yang digunakan untuk operasi perusahaan dalam menghasilkan keuntungan. Return on asset adalah rasio yang diperoleh dengan membagi laba/rugi bersih dengan total asset. Semakin tinggi nilai ROA semakin efektif pula pengelolaan aktiva perusahaan.

Dan penelitian sebelumnya, yaitu Linda Vania Wijaya dan Lauw Tjun Tjun (2017) melakukan penelitian atas Pengaruh Cash Turnover, Receivable Turnover, dan Inventory Turnover Terhadap Return On Asset Perusahaan Sektor Makanan dan Minuman yang Terdaftar di Bursa Efek Indonesia Periode 2013 - 2015, menyatakan bahwa secara parsial terdapat pengaruh antara Cash Turnover terhadap Return On Asset, secara parsial tidak terdapat pengaruh antara Receivable Turnover terhadap Return On Asset, secara parsial terdapat pengaruh antara Inventory Turnover terhadap Return On Asset dan secara parsial terdapat pengaruh antara Inventory Turnover terhadap Return On Asset pada perusahaan sektor makanan dan minuman yang tercatat di Bursa Efek Indonesia periode tahun 2013-2015 di Bursa Efek Indonesia.

Arianti, Ririn dan N. Rusnaeni (2018) melakukan penelitian atas pengaruh perputaran piutang, perputaran kas dan perputaran persediaan terhadap profitabilitas PT. Ultrajaya milk industry \& trading company, tbk, menyatakan bahwa Variabel perputaran piutang (X1) tidak berpengaruh signifikan terhadap variabel profitabilitas (Y), Variabel perputaran kas (X2) tidak berpengaruh signifikan terhadap variabel profitabilitas (Y), Variabel perputaran persediaan (X3) tidak berpengaruh signifikan terhadap variabel profitabilitas (Y) dan Secara simultan variabel Perputaran piutang, perputaran kas dan perputaran persediaan tidak berpengaruh terhadap profitabilitas.

Widiasmoro, Rio (2017) melakukan penelitian atas pengaruh perputaran kas, perputaran piutang, dan perputaran persediaan terhadap profitabilitas / ROA pada perusahaan manufaktur yang terdaftar di Bursa Efek Indonesia tahun 2011-2014, dalam penelitiannya menunjukkan bahwa Variabel perputaran kas berpengaruh signifikan terhadap profitabilitas ( ROA ), Variabel perputaran piutang berpengaruh signifikan terhadap profitabilitas ( ROA ), Variabel perputaran 46 | B u a n I $1 \mathrm{~m}$ u 
Anna Eka Gustriyana, Nunung Nurhasanah

Vol 4 No 2

ISSN : 2541-6995

E ISSN : 2580-5517

persediaan berpengaruh signifikan terhadap profitabilitas ( ROA ) dan secara simultan, variabel perputaran kas, perputaran piutang, dan perputaran persediaan berpengaruh signifikan terhadap profitabilitas ( ROA ).

Dan Utami, Nurul Pratiwi (2014) melakukan penelitian terhadap pengaruh perputaran kas, perputaran piutang, perputaran persediaan terhadap profitabilitas perusahaan non perbankan yang terdaftar pada LQ-45 periode 2008-2012. Dari pengujian secara parsial, dapat disimpulkan bahwa pada perputaran kas berpengaruh secara signifikan terhadap Return On Assets. Sedangkan pada perputaran piutang dan perputaran persediaan tidak berpengaruh secara signifikan terhadap Return On Assets. Hasil pengujian secara simultan dapat disimpulkan bahwa Perputaran Kas, Perputaran Piutang dan Perputaran Persediaan berpengaruh secara signifikan terhadap Return On Assets.

Berdasarkan data yang diperoleh dari Bursa Efek Indonesia untuk 30 (tiga puluh) perusahaan property dan real estate, menyajikan perputaran kas, perputaran piutang, perputaran persediaan dan pengaruhnya terhadap ROA akhir tahun 2017, diketahui bahwa perputaran kas, perputaran piutang, dan perputaran persediaan mempunyai pengaruh yang bervariatif terhadap profitabilitas perusahaan Property dan Real estate akhir tahun 2017, sebagai contoh pada PT.Cowell Development Tbk. perputaran kas sebesar 20,99 kali perputaran piutang sebesar 7,09 kali dan perputaran persedian sebesar 0,36 kali, pengaruhnya negatif terhadap ROA sebesar $(1,93) \%$ perlakuan sebaliknya pada PT. Jaya Real Property Tbk perputaran kas, sebesar 4,51 kali, perputaran piutang sebesar 32,64 kali dan perputaran persediaan sebesar 0,38 kali berpengaruh positif terhadap ROA sebesar 11,79\%. Dari phenomena diatas cukup menarik bagi penulis untuk meneliti lebih dalam tentang pengaruh perputaran kas, perputaran piutang, dan perputaran persediaan terhadap Return On Assets (ROA) dan Return On Equity (ROE) studi pada Perusahaan property dan Realestate yang Terdaftar di Bursa Efek Indonesia Tahun 2012 sampai dengan 2017.

\section{METODE PENELITIAN}

\section{Jenis Penelitian}

Metode penelitian yang akan digunakan dalam penelitian ini adalah metode deskriptif dan verifikatif, karena adanya variable-variabel yang akan ditelaah hubungannya serta tujuannya untuk menyajikan gambaran secara akurat mengenai fakta-fakta serta hubungan antar variabel yang diteliti, yaitu pengaruh perputaran kas, perputaran piutang, dan perputaran persediaan terhadap profitabilitas (ROA). Menurut Sugiyono (2012:4) mengemukakan bahwa metode 47 | B u a n I $1 \mathrm{mu}$ 
Anna Eka Gustriyana, Nunung Nurhasanah

Vol 4 No 2

ISSN : 2541-6995

E ISSN : 2580-5517

penelitian pada dasarnya merupakan cara ilmiah untuk mendapatkan data dengan tujuan dan kegunaan tertentu dengan ciri-ciri keilmuan,yaitu rasional, empiris dan sistematis.

Menurut Sugiyono (2012:53) metode desktiptif adalah Suatu rumusan masalah yang berkenaan dengan pertanyaan terhadap keberadaan variabel mandiri, baik hanya pada satu variabel atau lebih (variabel mandiri adalah variabel yang berdiri sendiri, bukan variabel independen karena kalau variabel independen selalu dipasangkan dengan variabel dependen. Metode deskriptif untuk menggambarkan kondisi tingkat perputaran kas, perputaran piutang, perputaran persediaan dan profitabilitas (ROA).

\section{Waktu dan Tempat Penelitian}

Studi pada perusahaan property dan real estate yang terdaftar di bursa efek indonesia periode $2012-2017$.

\section{Target/Subjek Penelitian}

Populasi dalam penelitian ini yaitu perusahaan property dan realestat yang dipublikasikan yang terdaftar di Bursa Efek Indonesia tahun 2012 sampai dengan 2017, sebanyak 48 perusahaan Prosedur Penelitian

Dalam penelitian ini terdapat variabel bebas (independen variabel) dan variabel terikat (dependen variabel). Variabel bebas adalah variabel yang nilainya tidak bergantung dari variabel yang lain dan variabel terikat adalah variabel yang nilainya tergantung dari variabel yang lain, variabel terikatnya adalah (Y) : Profitabilitas (ROA), variabel bebasnya adalah (X1) adalah perputaran Kas, (X2) adalah perputaran piutang, (X3) adalah perputaran persediaan.

\section{Data, Instrumen, dan Teknik Pengumpulan Data}

Pengumpulan data dilakukan dengan menggunakan metode studi kepustakaan dan dokumentasi yaitu dengan mencari data mengenai hal atau variabel yang berupa data-data tertulis seperti bukubuku, majalah, dokumen, dan peraturan-peraturan. Data dalam penelitian ini merupakan data sekunder dan sampel yang digunakan yang didasarkan pada laporan keuangan yang dipublikasikan di Bursa Efek Indonesia (Bursa Efek Indonesia) melalui Indonesia Stock Exchange (IDX).

\section{Teknik Analisis Data}

Salah satu teknik analisis data pada penelitan ini Menurut Sugiyono (2004:169) Analisis deskriptif adalah statistik yang digunakan untuk menganalisa data dengan cara mendeskripsikan atau menggambarkan data yang telah terkumpul sebagaimana adanya tanpa bermaksud membuat kesimpulan yang berlaku untuk umum atau generalisasi. Analisis verifikatif menurut Sugiyono (2008:13) Merupakan metode analisis yang berlandaskan pada filasafat positivis, digunakan untuk 
Anna Eka Gustriyana, Nunung Nurhasanah

Vol 4 No 2

ISSN : 2541-6995

E ISSN : 2580-5517

meneliti pada populasi dan sampel tertentu. Analisis data bersifat kuantitatif atau lebih dikenal dengan statistic dilakukan dengan tujuan menguji hipotesis yang telah ditetapkan. Analisis ini bermaksud untuk mengetahui hasil penelitian berkaitan dengan pengaruh perputaran kas, perputaran piutang, dan perputaran persediaan terhadap profitabilitas (ROA). Dalam penelitian ini, penulis menggunakan metode analisis regresi berganda. Penelitian ini merupakan penelitian yang bertujuan untuk mengetahui pengaruh variabel independen $(\mathrm{X})$ terhadap variabel dependen $(\mathrm{Y})$. Oleh karena itu untuk mengetahui hubungan antara variabel digunakan persamaan regresi berganda.

\section{HASIL PENELITIAN DAN PEMBAHASAN}

\section{Hasil Penelitian}

\section{Uji Normalitas}

Uji normalitas data dilakukan untuk mengetahui apakah dalam sebuah model regresi, variabel dependen, variabel independent atau keduanya mempunyai distribusi normal atau tidak berdistribusi normal.Metode regresi yang baik adalah distribusi data normal atau mendekati normal. Uji normalitas data menggunakan program SPSS disajikan dalam bentuk grafik pada gambar: 4.1 .

\section{Gambar : 4.1}

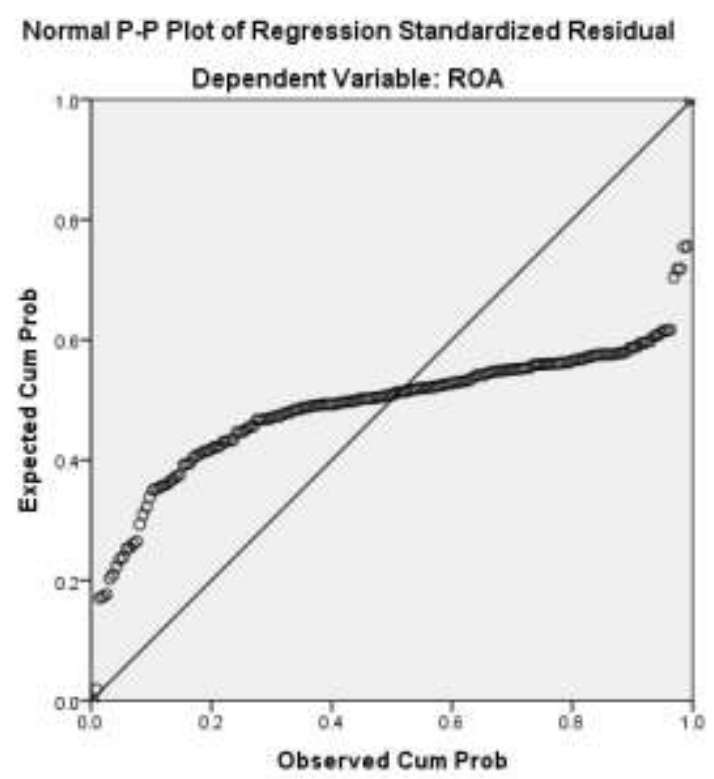

Data pengambilan keputusan uji normalitas data menurut Santoso (2002:213) yaitu: 
Anna Eka Gustriyana, Nunung Nurhasanah

Vol 4 No 2

ISSN : 2541-6995

E ISSN : 2580-5517

1. Jika data menyebar di sekitar garis diagonal dan mengikuti arah garis diagonal, maka model regresi memenuhi asumsi Normalitas.

2. Jika data menyebar jauh dari garis diagonal dan/atau tidak mengikuti arah garis diagonal, maka model regresi tidak memenuhi asumsi Normalitas.

Dari gambar 4.1 terlihat titik-titik menyebar di sekitar garis diagonal, serta penyebarannya mengikuti arah garis diagonal. Maka model regresi ini memenuhi asumsi normalitas dan layak dipakai untuk meneliti variabel ROA (Y) berdasarkan masukan variabel perputaran kas (X1), perputaran piutang (X2), dan perputaran persediaan (X3).

\section{Uji Multikolinieritas}

Uji multikolinearitas adalah suatu keadaan dimana antar variabel X (bebas) saling berkorelasi satu dengan yang lainnya. Jika suatu persamaan regresi berganda terjadi multikolinearitas di antara variabel-variabel bebasnya, maka variabel-variabel yang berkolinearitas tidak memberikan informasi apa-apa pada variabel. Karena itu, persamaan regresi berganda yang baik adalah persamaan yang bebas dari adanya multikolinearitas antar variabel bebasnya. Gejala adanya multikolinearitas dapat dideteksi dengan menggunakan Pearson Correlation dan Tolerance Value serta Varian Inflation Factor (VIF). Batas tolerance value adalah 0,10 dan batas VIF adalah 10. Jika tolerance value dibawah 0,10 atau nilai VIF diatas 10, maka dapat dipastikan telah terjadi multikolinearitas (Ghozali, 2011). Uji multikolinearitas menggunakan besaran VIF (Varian Inflation Factor) seperti pada tabe; 4.1

\section{Tabel 4.1}

Uji Multikolinieritas dengan VIF

Coefficients $^{\mathrm{a}}$

\begin{tabular}{|c|c|c|c|c|c|c|c|}
\hline \multirow[b]{2}{*}{ Model } & \multicolumn{2}{|c|}{$\begin{array}{l}\text { Unstandardized } \\
\text { Coefficients }\end{array}$} & \multirow{2}{*}{$\begin{array}{c}\text { Standar } \\
\text { dized } \\
\text { Coeffici } \\
\text { ents } \\
\\
\text { Beta } \\
\end{array}$} & \multirow[b]{2}{*}{$t$} & \multirow[b]{2}{*}{ Sig. } & \multicolumn{2}{|c|}{ Collinearity Statistics } \\
\hline & $\mathrm{B}$ & $\begin{array}{l}\text { Std. } \\
\text { Error }\end{array}$ & & & & Tolerance & VIF \\
\hline \begin{tabular}{l|l}
1 (Constant) \\
\end{tabular} & -53.689 & 21.835 & & -2.459 & .015 & & \\
\hline Perputaran Kas & 10.675 & 1.614 & .447 & 6.614 & .000 & .962 & 1.040 \\
\hline Perputaran Piutang & 1.686 & 1.109 & .103 & 1.521 & .130 & .954 & 1.048 \\
\hline Perputaran Persediaan & -.069 & .526 & -.009 & -.131 & .896 & .982 & 1.019 \\
\hline
\end{tabular}

Dari tabel di atas dapat diketahui ada atau tidaknya problem multikolinieritas pada variabel yang diteliti. Dasar pengambilan keputusan yang digunakan adalah besaran VIF (Varian Inflation 
Anna Eka Gustriyana, Nunung Nurhasanah

Vol 4 No 2

ISSN : 2541-6995

E ISSN : 2580-5517

Factor) dan Tolerance dimana pedoman suatu model regresi yang bebas dari multikolinearitas memenuhi kriteria mempunyai nilai VIF di atas 0,10 dan mempunyai angka Tolerance dibawah 10.

Berdasarkan tabel di atas pada bagian Coefficient dapat dilihat ketiga variabel independen, angka VIF ada di bawah $10(X 1=1.040, X 2=1.048, X 3=1.019)$. Demikian juga nilai Tolerance berada di atas $0,10(\mathrm{X} 1=0.962, \mathrm{X} 2=0.954, \mathrm{X} 3=0.982)$. Dengan demikian dapat disimpulkan bahwa model regresi tersebut tidak terdapat problem multikolinieritas baik berdasarkan pada besara VIF maupun besaran korelasi antar variabel.

\section{Uji Heterokedastisitas}

Tujuannya adalah untuk menguji apakah dalam sebuah model regresi terjadi ketidaksamaan varians dari residual dari satu pengamatan ke pengamatan yang lain. Jika varians dari residual dari satu pengamatan ke pengamatan yang lain tetap, maka disebut Homoskedastisitas. Dan jika varians berbeda, disebut Heteroskedastisitas. Sedangkan model regresi yang baik adalah tidak terjadi adanya Heteroskedastisitas. Pengujian ada tidaknya Heteroskedastisitas terhadap ke 4 variabel disajikan pada gambar 4.2

\section{Gambar 4.2}

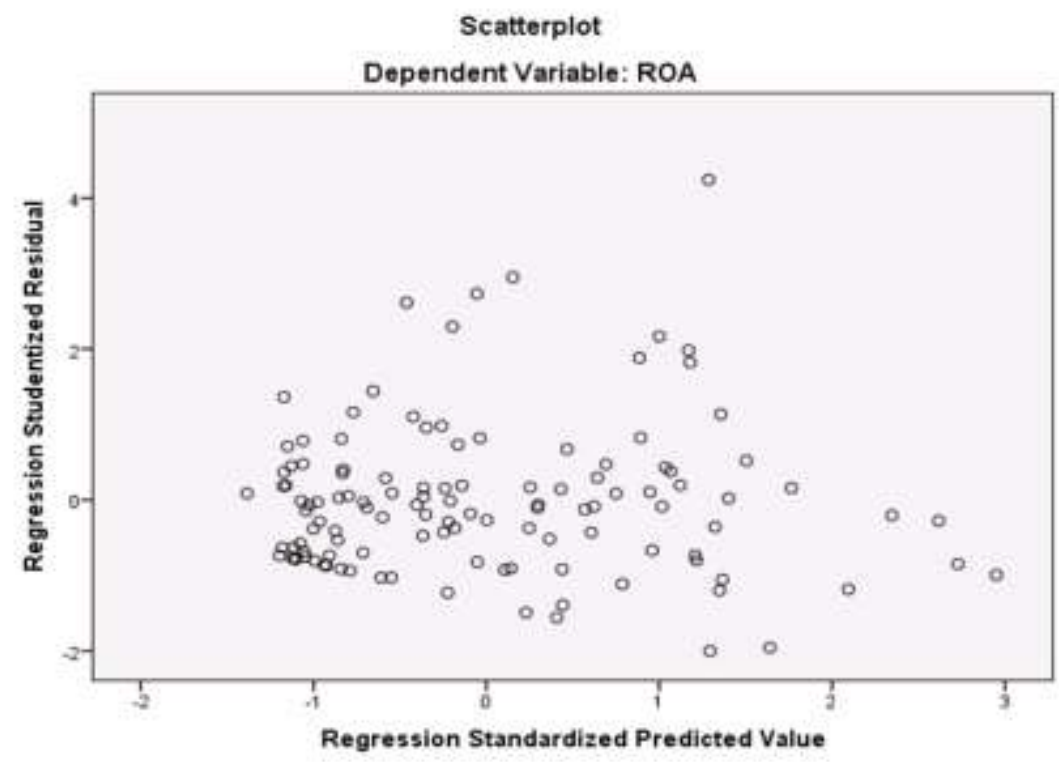

Dasar pengambilan keputusan :

1. Jika pada model regresi terdapat pola tertentu, seperti titik-titik (point-point) yang ada membentuk suatu pola tertentu yang teratur (bergelombang, melebar kemudian menyempit), maka telah terjadi Heteroskedastisitas. 
Anna Eka Gustriyana, Nunung Nurhasanah

Vol 4 No 2

ISSN : 2541-6995

E ISSN : 2580-5517

2. Jika tidak ada pola yang jelas pada model regresi, serta titik-titik menyebar di ataas dan di bawah angka 0 pada sumbu Y, maka tidak terjadi Heteroskedastisitas.

Beradasarkan gambar 4.2 terlihat titik-titik menyebar secara acak, tidak membentuk sebuah pola tertentu yang jelas, serta tersebar baik di atas maupun di bawah angka 0 pada sumbu Y. Hal ini berarti tidak terjadi heteroskedastisitas pada model regresi tersebut, sehingga model regresi layak dipakai untuk prediksi variabel $\mathrm{ROA}(\mathrm{Y})$ berdasarkan masukan variabel perputaran kas (X1), perputaran piutang (X2), dan perputaran persediaan (X3).

\section{Uji Autokorelasi}

Menguji apakah dalam sebuah model regresi linier ada korelasi antara kesalahan pengganggu pada periode $\mathrm{t}$ dengan kesalahan pada periode t-1 (sebelumnya). Jika terjadi korelasi, maka dinamakan ada masalah autokorelasi. Model regresi yang baik adalah regresi yang bebas dari autokorelasi. Berikut disajikan pengujian Autokorelasi ke 4 variabel dengan model Durbin Watson SPSS.

\section{Tabel 4.2 Durbin Watson}

\begin{tabular}{|l|r|r|r|r|r|}
\hline & & & \multicolumn{2}{|c|}{ Model Summary } \\
Model & $\mathrm{R}$ & $\mathrm{R}$ Square & \multicolumn{1}{c|}{$\begin{array}{c}\text { Square } \\
\text { Squated }\end{array}$} & $\begin{array}{c}\text { Std. Error of the } \\
\text { Estimate }\end{array}$ & $\begin{array}{c}\text { Durbin-Watson } \\
\text { (DW) }\end{array}$ \\
\hline 1 & $.477^{\mathrm{a}}$ & .227 & .214 & 198.127203 & 2.033 \\
\hline
\end{tabular}

Dari tabel 4.2 diketahui ada atau tidaknya problem autokorelasi pada variabel yang diteliti. Dasar pengambilan keputusan adanya autokorelasi dengan menggunakan besaran Durbin Watson yang secara umum dapat diambil patokan yaitu: (Ghozali:2009).

a. Jika d lebih kecil dari dL atau lebih besar dari (4-dL), maka hipotesis nol ditolak, yang berarti terdapat autokorelasi.

b. Jika d terletak antara dU dan (4-dU), maka hipotesis nol diterima, yang berarti tidak ada autokorelasi.

c. Jika d terletak antara dL dan dU atau diantara (4-dU) dan (4-dL), maka tidak menghasilkan kesimpulan yang pasti.

Berdasarkan tabel 4.2 dilihat pada bagian Model Summary, terlihat angka D-W untuk ROA sebesar 2.033, nilai ini dibandingkan dengan nilai tabel signifikasi $5 \%$, jumlah sampel 180 (n) dan jumlah variabel independen $3(\mathrm{~K}=3)$, diperoleh nilai $\mathrm{dL}=2,2099$ dan nilai $\mathrm{dU}=1,7901$. Dari nilai tersebut diketahui bahwa nilai DW lebih besar dari batas dU dan kurang dari batas 4-dU. 
Anna Eka Gustriyana, Nunung Nurhasanah

Vol 4 No 2

ISSN : 2541-6995

E ISSN : 2580-5517

Berdasarkan analisis asumsi klasik dapat disimpulkan bahwa analisis regresi sederhana dan berganda dari variabel independen Perputaran kas (X1), Perputaran Piutang (X2), dan Perputaran Persediaan (X3) terhadap variabel dependen Return On Asset (ROA) memenuhhi syarat korelasi, karena :

1. Uji Normalitas Data, titik-titik menyebar data berada disekitar garis diagonal, serta penyebarannya mengikuti arah garis diagonal. Maka model regresi ini memenuhi asumsi normalitas.

2. Uji Multikolinieritas, tidak terjadi masalah multikolinieritas pada model regresi tersebut, sehingga model regresi layak dipakai untuk prediksi regresi.

3. Uji Heterokedastisitas, tidak terjadi Heteroskedastisitas pada model regresi tersebut, sehingga model regresi layak dipakai untuk prediksi regresi.

4. Uji Autokorelasi, bahwa tidak ada masalah autokorelasi

\section{Transformasi Data}

Penelitian ini menggunakan data laporan keuangan perusahaan property dan realestate yang telah dipublikasikan pada perusahaan property dan realestate yang telah terdaftar di Bursa Efek Indonesia melalui website www.idx.co.id.

\section{Analisis Deskriptif}

Deskripsi data penelitian dari masing-masing variabel rasio keuangan meliputi data Perputaran Kas, Perputaran Piutang, Perputaran Persediaan, Return On Asset (ROA) dalam perusahaan bergerak disektor Property dan Realestate.

\section{Pembahasan}

1. Berdasarkan hasil penelitian, bahwa hasil uji t menyatakan bahwa variabel Perputaran Kas memiliki t hitung sebesar 6,614>t tabel sebesar 1,653 dengan dengan nilai significance (2-tailed) $0,000<0,05$. Hal tersebut dapat diartikan bahwa variabel Perputaran Kas memiliki pengaruh yang signifikan terhadap profitabilitas (Return On Asset). Besaran pengaruh parsialnya sebesar 46,6\%, artinya bahwa perputaran kas akan mempengaruhi profitabilitas (Return On Asset) sebesar 46,6\%.

2. Berdasarkan hasil penelitian, bahwa hasil uji t menyatakan bahwa variabel Perputaran Piutang memiliki t hitung sebesar 1,521 < t tabel sebesar 1,653 dengan dengan nilai significance (2-tailed) $0,130>0,05$. Hal tersebut dapat diartikan bahwa variabel perputaran piutang tidak berpengaruh terhadap profitabilitas (Return On Asset). 
3. Berdasarkan hasil penelitian, bahwa hasil uji t menyatakan bahwa variabel Perputaran Persediaan memiliki $\mathrm{t}$ hitung sebesar $-0,131<\mathrm{t}$ tabel sebesra 1,653 dengan nilai significance (2-tailed) $0,896>0,05$. Hal tersebut dapat diartikan bahwa variabel perputaran persediaan tidak berpengaruh terhadap profitabilitas (Return On Asset).

4. Perhitungan hasil Uji F didapatkan nilai F hitung sebesar 17,241 lebih besar dari F tabel $(0,05)$ sebesar 2,66, maka HO ditolak atau HI diterima berarti Perputaran Kas, Perputaran Piutang dan Perputaran Persediaan secara bersama-sama memiliki pengaruh yang signifikan terhadap Profitabilitas (Return On Asset). Hal ini menunjukkan hipotesis bahwa variabel independen yaitu Perputaran Kas, Perputaran Piutang dan Perputaran Persediaan secara bersama-sama (simultan) berpengaruh dan signifikan terhadap variabel dependen yaitu Profitabilitas (Return On Asset) .

5. Koefisien determinasi $\left(R^{2}\right)$ menyatakan bahwa Nilai $R$ Square $=0,214$ atau $21,4 \%$. Hal ini menjelaskan bahwa kontribusi yang diberikan variabel Perputaran Kas (X1), Perputaran Piutang (X2), dan Perputaran Persediaan (X3) terhadap Profitabilitas (Return On Asset) sebesar 21,4\% sedangkan sisanya sebesar 78,6\% dipengaruhi oleh factor-faktor lain yang tidak diteliti. Dengan demikian Perputaran Kas (X1), Perputaran Piutang (X2), dan Perputaran Persediaan (X3) apabila dilakukan bersama-sama akan meningkatkan Profitabilitas (Return On Asset) sebesar 21,4\%.

\section{KESIMPULAN DAN IMPLIKASI}

\section{Kesimpulan}

Berdasarkan hasil penelitian dan pembahasan pada bab-bab sebelumnya dapat dikemukakan beberapa kesimpulan sebagai berikut :

a. Perputaran Kas berpengaruh signifikan terhadap Profitabilitas (Return On Asset) pada perusahaan property dan real estate yang terdaftar di Bursa Efek Indonesia periode tahun 2012 - 2017, Hal ini menunjukan bahwa perusahaan telah efektif dan efisien dalam pengelolaan kas.

b. Perputaran Piutang tidak berpengaruh terhadap Profitabilitas (Return On Asset) pada perusahaan property dan real estate yang terdaftar di Bursa Efek Indonesia periode tahun 2012 - 2017, hal ini menunjukan bahwa perusahaan belum efektif dalam pengelolaan piutang. 
Anna Eka Gustriyana, Nunung Nurhasanah

Vol 4 No 2

ISSN : 2541-6995

E ISSN : 2580-5517

c. Perputaran Persediaan tidak berpengaruh terhadap profitabilitas (Return On Asset) pada perusahaan property dan real estate yang terdaftar di Bursa Efek Indonesia periode tahun 2012 - 2017, hal ini menunjukan bahwa perusahaan belum efektif dalam pengelolaan persediaan.

d. Perputaran Kas, Perputaran Piutang dan Perputaran Persediaan secara simultan berpengaruh signifikan terhadap variabel dependen yaitu Profitabilitas (Return On Asset) pada perusahaan property dan real estate yang terdaftar di Bursa Efek Indonesia periode tahun 2012 - 2017, hal ini menunjukan perusahaan mampu mengelola kas, piutang dan persediaan secara efektif dan efisien.

\section{Implikasi}

Untuk penelitian yang akan datang peneliti bisa meneliti faktor-faktor lain yang dimungkinkan mempengaruhi Profitabilitas (Return On Asset) yaitu aktiva tetap, biaya operasional perusahaan dan penjualan.

\section{DAFTAR PUSTAKA}

Sutrisno, 2017. Manajemen Keuangan Teori Konsep dan Aplikasi. Penerbit Ekonisia, Yogyakarta.

Sutrisno, 2012. Manajemen Keuangan Teori Konsep dan Aplikasi. Penerbit Ekonisia, Yogyakarta.

Sutrisno, 2010. Manajemen Keuangan Teori Konsep dan Aplikasi. Penerbit Ekonisia, Yogyakarta.

Sutrisno, 2004. Manajemen Keuangan Teori Konsep dan Aplikasi. Penerbit Ekonisia, Yogyakarta.

Brigham Houston, 2010. Dasar-dasar Manajemen Keuangan. Salemba Empat, Jakarta Suad Husnan, Enny Pudjiastuti. 2012. Dasar-dasar Manajemen Keuangan. UPP STIM YKPN, Yogyakarta.

Bambang Riyanto, 2008. Dasar-dasar Pembelajaran Perusahaan, BPFE, Yogyakarta.

Agnes Sawir, 2009. Analisa Kinerja Keuangan dan Perencanaan keauangan Perusahaan, PT. Gramedia Pustaka Utama, Jakarta.

Lukman Syamsuddin, 2001. Manajemen Keuangan Perusahaan, PT. Raja Grafindo Persada, Jakarta.

Kasmir, 2008, Analisis Laporan Keuangan, Rajawali Pers, Jakarta.

Irham Fahmi, 2013. “Pengantar Manajemen Keuangan Teori dan Soal jawab”. Cetakan 
Anna Eka Gustriyana, Nunung Nurhasanah

Vol 4 No 2

ISSN : 2541-6995

E ISSN : 2580-5517

Kedua. Bandung: Alfabeta.

Arfan Ikhsan dan Teddy Prianthara I.B. 2009. “Akuntansi Untuk Manajer”. Edisi Pertama.

Cetakan pertama. Yogyakarta: Graha Ilmu.

Kasmir. 2013. “Analisis Laporan Keuangan”. Edis 1. Cetakan ke-6. Jakarta: Rajawali Pers.

Kieso, Weygandt dan Warfield. 2008. "Akuntansi Keuangan”. Edisi Keduabelas. Jilid Satu.

Jakarta: Erlangga.

Manullang, Marihot dan Sinaga, Dearlina. 2007. "Pengantar Manajemen Keuangan”. Edisi

Pertama. Yogyakarta:

Rudianto. 2009. "Pengantar Akuntansi". Cetakan Pertama. Jakarta: Erlangga.

Harahap, Sofyan. S. 2008. “Analisis Kritis atas Laporan Keuangan”. Jakarta: PT

Rajagrafindo Persada.

Santoso, Singgih. 2014. Statistik Parametrik "Konsep dan Aplikasi dengan SPSS” Edisi Revisi. Jakarta: PT Elex Media Komputindo.

Suharyadi dan Purwanti,S.K. 2009. Statistika “untuk Ekonomi dan Keuangan Modern.” Edisi 2 Jakarta:Salemba Empat.

Warren, Carl S. Reeve, James M. dan Fess, Philip E.2008. "Pengantar Akuntansi”. Buku Satu-Edisi 21. Jakarta: Salemba Empat.

Weygandt. Jerry J, Kieso, Donald E dan Kimmmel, Paul D. 2008. “Accounting Principles”. Edisi Tujuh.Salemba Empat.

Ridwan dan Engkos A Kuncoro 2014. "Cara Menggunakan dan Memaknai Path Analysis". Bandung: Alfabeta.

Imam Ghozali. 2016. Aplikasi Analisis Multivariete dengan Program IBM SPSS 23.

Semarang : BP. Universitas Diponegoro.

Sugiyono.2009. Metode Penelitian Bisnis. Bandung: Alfabeta CV.

Sugiyono.2010. Metode Penelitian Kuantitatif Kualitatif dan R\&D. Bandung: Alfabeta CV

G. Sugiyarso dan F. Winarni. 2005. “Manajemen Keuangan”. Yogyakarta: Media Pressindo http://www.idx.co.id

Wijaya, Linda Vania, Lauw Tjun Tjun (2017). Pengaruh Cash Turnover, Receivable

Turnover, dan Inventory Turnover Terhadap Return On Asset Perusahaan Sektor Makanan dan Minuman yang Terdaftar di Bursa Efek Indonesia Periode 2013 2015.

Arianri, Ririn, Rusnaeni, N (2018). Pengaruh perputaran piutang, perputaran kas dan perputaran persediaan terhadap profitabilitas PT. Ultrajaya Milk Industry \& 
Anna Eka Gustriyana, Nunung Nurhasanah

Vol 4 No 2

ISSN : 2541-6995

E ISSN : 2580-5517

Trading Company, tbk.

Widiasmoro, Rio (2017). Pengaruh Perputaran Kas, Perputaran Piutang, Dan Perputaran

Persediaan Terhadap Profitabilitas / ROA Pada Perusahaan Manufaktur Yang

Terdaftar Di Bursa Efek Indonesia Tahun 2011-2014.

http://eprints.upnyk.ac.id/id/eprint/1135 Hermawati, Anita (2016) ), Pengaruh Perputaran

Piutang, Perputaran Kas, dan Perputaran Persediaan terhadap Profitabilitas

Periode 2010- 2013 ( Studi Empiris Pada Perusahaan Property dan Real estate di

Bursa Efek Indonesia)

http://library.gunadarma.ac.id/repository/view/3803380/ Nurulinar H (2015),Pengaruh

Perputaran Kas, Perputaran Piutang, dan Perputaran Persediaan terhadap

Profitabilitas Pada Perusahaan Property dan Real estate di yang terdaftar di Bursa

Efek Indonesia Periode 2010 - 2013.

Utami, Nurul Pratiwi (2014) Pengaruh perputaran kas, perputaran piutang, perputaran persediaan terhadap profitabilitas perusahaan non perbankan yang terdaftar pada LQ-45 periode 2008-2012.

Herlina puji astuti, (2005) Pengaruh Modal Kerja Dan Perputaran Modal Kerja terhadap return on equity (ROE) pada perusahaan makanan dan minuman go public di Bursa Efek Jakarta.

Ika Yuli Wijayanti, (2007) Pengaruh Modal Kerja Dan Perputaran Modal Kerja Terhadap Return On Equity (ROE) Pada Perusahaan Manufaktur Yang Terdaftar Di Bursa Efek Jakarta

eujournal.org/files/journals/1/articles/.../2568-7591-1-PB.pdf Hina Agha, Mba, Mphil (2014) Impact of working capital management on profitability. European Scientific Journal January 2014 edition vol.10, No 1 ISSN: 1857 - 7881 (Print) e - ISSN 1857- 7431. COPY RIGHT (C) 2013 Institute of Interdisciplinary Business Research. Impact Of Working Capital Management On Profitability A Case Of The Pakistan Cement Industry. Zubair Arshad, Muhammad Yasir Gondal, CFE College Pakistan. (2013)

www.finance.detik.com data di download pada tanggal 20 Maret 2019 https://katadata.co.id/berita data di download pada tanggal 22 Maret 2019 www.wikipedia.org data di download pada tanggal 20 Maret 2019 www.bps.go.id data di download pada tanggal 19 Maret 2019 www.harnas.co/2017/01/09/...property/perkembangan-pasar-property- indonesia. Strategi

Mendorong Sektor Property. 